\title{
Proper Management of People with Obesity during the COVID-19 Pandemic
}

\author{
Soo Lim ${ }^{1,2 *}$, Soo Myoung Shin ${ }^{1,2}$, Ga Eun Nam ${ }^{3}$, Chang Hee Jung ${ }^{4}$, Bo Kyung Koo ${ }^{2,5}$ \\ ${ }^{1}$ Department of Internal Medicine, Seoul National University Bundang Hospital, Seongnam; ${ }^{2}$ Department of Internal Medicine, Seoul National University College of \\ Medicine, Seoul; ${ }^{3}$ Department of Family Medicine, Korea University College of Medicine, Seoul; ${ }^{4}$ Department of Internal Medicine, Asan Medical Center, University of \\ Ulsan College of Medicine, Seoul; ${ }^{5}$ Department of Internal Medicine, SMG-SNU Boramae Medical Center, Seoul, Korea
}

Since December 2019, countries around the world have been struggling with a novel coronavirus, severe acute respiratory syndrome coronavirus 2 (SARS-CoV-2). Case series have reported that people with obesity experience more severe coronavirus disease 2019 (COVID-19). During the COVID-19 pandemic, people have tended to gain weight because of environmental factors imposed by quarantine policies, such as decreased physical activity and increased consumption of unhealthy food. Mechanisms have been postulated to explain the association between COVID-19 and obesity. COVID-19 aggravates inflammation and hypoxia in people with obesity, which can lead to severe illness and the need for intensive care. The immune system is compromised in people with obesity and COVID-19 affects the immune system, which can lead to complications. Interleukin-6 and other cytokines play an important role in the progression of COVID-19. The inflammatory response, critical illness, and underlying risk factors may all predispose to complications of obesity such as diabetes mellitus and cardiovascular diseases. The common medications used to treat people with obesity, such as glucagon-like peptide-1 analogues, statins, and antiplatelets agents, should be continued because these agents have anti-inflammatory properties and play protective roles against cardiovascular and all-cause mortality. It is also recommended that renin-angiotensin system blockers are not stopped during the COVID-19 pandemic because no definitive data about the harm or benefits of these agents have been reported. During the COVID-19 pandemic, social activities have been discouraged and exercise facilities have been closed. Under these restrictions, tailored lifestyle modifications such as home exercise training and cooking of healthy food are encouraged.

\author{
Received June 2, 2020 \\ Reviewed June 8, 2020 \\ Accepted June 11, 2020 \\ *Corresponding author \\ Soo Lim \\ https://orcid.org/0000-0002-4137-1671 \\ Department of Internal Medicine, Seoul \\ National University Bundang Hospital, \\ Seoul National University College of \\ Medicine, 82 Gumi-ro 173beon-gil, \\ Bundang-gu, Seongnam 13620, Korea \\ Tel: +82-31-787-7035 \\ Fax: +82-31-787-4051 \\ E-mail:limsoo@snu.ac.kr
}

The first two authors contributed equally to this study.

Key words: Obesity, SARS-CoV-2, COVID-19, Cardiovascular disease, Mortality

\section{INTRODUCTION}

Severe acute respiratory syndrome coronavirus 2 (SARS-CoV-2) is a positive-stranded RNA virus and has $82 \%$ homology with that of human SARS-CoV. Genomic analyses indicate $89 \%$ nucleotide identity with bat SARS-like-CoVZXC21 and suggests that SARSCoV-2 evolved from bats. The potential for amplification from the mammalian host intermediate between bats and humans is unknown. SARS-CoV-2 enters human cells mainly by binding to the angiotensin-converting enzyme 2 (ACE2), ${ }^{1}$ which is highly ex- pressed in lung alveolar cells, cardiac myocytes, the vascular endothelium, and other cells. ${ }^{2}$ SARS-CoV-2 is transmitted primarily after viral particles are inhaled and enter the respiratory tract. ${ }^{3}$

Generally, people with coronavirus disease 2019 (COVID-19) caused by SARS-CoV-2 develop signs and symptoms on average of 5-6 days after infection. The disease induces mild symptoms in the initial stage but can cause severe illness including systemic inflammatory response syndrome, acute respiratory disease syndrome, multiorgan involvement, and shock. ${ }^{4}$ According to the most recent data, the fatality rate is $6.0 \%$ worldwide. A high mortality rate has

Copyright (C) 2020 Korean Society for the Study of Obesity

(a) This is an Open Access article distributed under the terms of the Creative Commons Attribution Non-Commercial License (https://creativecommons.org/licenses/by-nc/4.o/) which permits unrestricted non-commercial use, distribution, and reproduction in any medium, provided the original work is properly cited. 
been observed in certain groups such as older populations and people with underlying health issues such as cardiovascular disease (CVD) and diabetes mellitus (DM). ${ }^{5} \mathrm{~A}$ few early studies have reported that obesity is associated with the severity of COVID-19.6-8 However, the features of COVID-19 in people with obesity have not been elucidated and it has not been determined whether obesity is an independent risk factor for susceptibility to infection with SARS-CoV-2 or the severity of COVID-19 or both.

\section{ASSOCIATION BETWEEN COVID-19 AND OBESITY}

We obtained data from a retrospective multicenter study in which all 28 of the first confirmed patients with COVID-19 in the Republic of Korea were enrolled. Five of these patients had a body mass index $(\mathrm{BMI})>30 \mathrm{~kg} / \mathrm{m}^{2}(18 \%) .{ }^{9}$ Zheng et al..$^{10}$ investigated 214 patients with laboratory-confirmed COVID-19 from three hospitals in Wenzhou, China, and compared patients with obesity and metabolic-associated fatty liver disease (MAFLD) with those with nonobese MAFLD. They found that obesity in patients with MAFLD was associated with a 6-fold increased risk of severe COVID-19 illness. Using retrospective data obtained for 103 patients hospitalized with COVID-19 at three hospitals in Rhode Island, USA, Kalligeros et al. ${ }^{8}$ reported an association between severe obesity (BMI $\geq 35 \mathrm{~kg} / \mathrm{m}^{2}$ ) and intensive care unit (ICU) admission. In that study, a history of heart disease and obesity $\left(\mathrm{BMI} \geq 30 \mathrm{~kg} / \mathrm{m}^{2}\right.$ ) was independently associated with the need for invasive mechanical ventilation. Publications that have investigated the associations between the extent of obesity and other conditions in patients with COVID-19 are summarized in Table 1.

During the COVID-19 pandemic, dietary patterns have changed to include increased reliance on delivered foods, and access to healthy food options has diminished. ${ }^{11}$ Delivered foods are mostly fast foods, such as pizza, hamburgers, fried chicken, and sugar-sweetened beverages or carbonated soda. ${ }^{12}$ These items are probably more obesogenic than home-cooked foods. ${ }^{13}$ Increased consumption of these foods is associated with increased risk of obesity and DM..$^{14,15}$

People with obesity or who are overweight are reported to be less active. ${ }^{16,17}$ In addition, during the COVID-19 pandemic, community health centers, gyms, swimming pools, and parks have been closed by law in many countries as part of their quarantine strategy. These changes in the food and social environments may have contributed to an increase in body weight in people with obesity as well as in the general population.

\section{ASSOCIATIONS BETWEEN COVID-19 AND OBESITY-RELATED DISEASES INCLUDING DM AND CVD}

A study of 44,672 confirmed Chinese patients with COVID-19 reported an overall case-fatality rate of $2.3 \%$ (1,023 deaths among 44,672 confirmed cases). ${ }^{4}$ In that study, the fatality rates were $8.0 \%$ in people aged $70-79$ years and $14.8 \%$ in those aged 80 years and older. In China, the fatality rate is higher among those with preexisting comorbid conditions-10.5\% for those with CVD, $7.3 \%$ for those with DM, and 6.0\% for those with hypertension. ${ }^{18}$ An early study of 1,099 patients with COVID-19 from 552 hospitals in China found that $23.7 \%$ of patients had one or more underlying diseases: hypertension in $15.0 \%$, coronary heart disease in $2.5 \%$, and DM in 7.4\%. Comparison between patients with severe disease ( $\mathrm{n}=173$; mean age, 52 years) with those with nonsevere disease ( $n=926$; mean age, 45 years) showed that patients with coronary heart disease and DM exhibited more severe disease than those without. For example, the rates of severe versus nonsevere diseases were $5.8 \%$ vs. $1.8 \%$ among the patients with coronary heart disease, $23.7 \%$ vs. $13.4 \%$ among those with hypertension, and $16.2 \%$ vs. $5.7 \%$ among those with DM. ${ }^{19}$

A meta-analysis of six studies that included a total of $1,527 \mathrm{pa}-$ tients with COVID-19 reported the prevalence rates of hypertension, CVD, and DM as $17.1 \%, 16.4 \%$, and $9.7 \%$, respectively. ${ }^{20}$ In a retrospective case series study in Lombardy, Italy, the most common underlying medical conditions among patients admitted to the ICU with COVID-19 were hypertension (49\%), CVD (21\%), and DM (17\%). ${ }^{21}$ According to the data from the Italian National Institute of Health, the fatality rate of COVID-19 was $35.5 \%$ in patients with DM.22 Early data from the US Centers for Disease Control and Prevention on March 28, 2020, reported that DM was the most prevalent health condition ( $10.9 \%$ prevalence) in people infected with SARS-CoV-2. The prevalence of DM was 32\% among patients admitted at ICU. ${ }^{23}$ In contrast, an epidemiological data re- 
Table 1. Summary of the literature on the clinical implications of obesity in the prognosis and severity of COVID-19

\begin{tabular}{|c|c|c|c|c|c|}
\hline Study (year) & Country & Total no. of patients & Patient with obesity, n (\%) & BMI cutoff & Summary of results \\
\hline Petrilli et al. $(2020)^{24}$ & US & 5,279 & $\begin{array}{l}\mathrm{BMI} \geq 30 \mathrm{~kg} / \mathrm{m}^{2}: 1,865(35.3) \\
30.0-39.9 \mathrm{~kg} / \mathrm{m}^{2}: 1,554(29.4) \\
\geq 40 \mathrm{~kg} / \mathrm{m}^{2}: 311(5.9)\end{array}$ & $\begin{array}{l}\geq 30 \mathrm{~kg} / \mathrm{m}^{2}\left(30.0-39.9 \mathrm{~kg} / \mathrm{m}^{2}\right. \\
\left.\geq 40 \mathrm{~kg} / \mathrm{m}^{2}\right)\end{array}$ & $\begin{array}{l}\text { Increased risk for hospital admission in BMl } \\
\geq 40 \mathrm{~kg} / \mathrm{m}^{2}(\mathrm{OR}, 2.5 ; 95 \% \mathrm{Cl}, 1.8-3.4) ; \\
\text { increased risk for critical illness in BMl } \\
\geq 40 \mathrm{~kg} / \mathrm{m}^{2}(\mathrm{OR}, 1.5 ; 95 \% \mathrm{Cl}, 1.0-2.2)\end{array}$ \\
\hline Klang et al. $(2020)^{25}$ & US & 3,406 & $\begin{array}{l}\text { BMI } 30-39.9 \mathrm{~kg} / \mathrm{m}^{2}: 957 \\
\quad \geq 40 \mathrm{~kg} / \mathrm{m}^{2}: 274\end{array}$ & $\begin{array}{l}30-39.9 \mathrm{~kg} / \mathrm{m}^{2} \\
\geq 40 \mathrm{~kg} / \mathrm{m}^{2}\end{array}$ & $\begin{array}{l}\text { Higher mortality (OR, 5.1; 95\% Cl, 2.3-11.1) in BMl } \\
\geq 40 \mathrm{~kg} / \mathrm{m}^{2}\end{array}$ \\
\hline Cai et al. $(2020)^{26}$ & China & 383 & $41(10.7)$ & $\begin{array}{l}\text { Overweight: } 24.0-27.9 \mathrm{~kg} / \mathrm{m}^{2} \\
\text { obesity: } \geq 28 \mathrm{~kg} / \mathrm{m}^{2}\end{array}$ & $\begin{array}{l}\text { Increased disease severity of COVID-19: OR, 1.84; } \\
95 \% \text { Cl, 0.99-3.43; in overweight: OR, 3.40; } 95 \% \\
\mathrm{Cl}, 1.40-2.86\end{array}$ \\
\hline Caussy et al. (202027 & France & 291 & $33(11.3)$ & Severe obesity: $\geq 35 \mathrm{~kg} / \mathrm{m}^{2}$ & $\begin{array}{l}\text { Higher requirement for IMV in patients with severe } \\
\text { obesity compared to lean patients ( } 81.8 \% \text { vs. } \\
41.9 \%, P=0.001 \text { ) }\end{array}$ \\
\hline Huang et al. (2020)28 & China & 202 & $24(14.0)$ & $\geq 28 \mathrm{~kg} / \mathrm{m}^{2}$ & $\begin{array}{l}\text { Increased severity of COVID-19 in BMl } \\
\geq 28 \text { kg/m² (OR, 9.22; 95\% Cl, 2.73-31.13) }\end{array}$ \\
\hline $\begin{array}{l}\text { Palaiodimos et al. } \\
(2020)^{29}\end{array}$ & US & 200 & $\begin{array}{l}\text { BMI } 25-34 \text { kg/m²: } 116 \text { (58), } \\
\geq 35 \mathrm{~kg} / \mathrm{m}^{2}: 46 \text { (23) }\end{array}$ & $\begin{array}{l}<25 \mathrm{~kg} / \mathrm{m}^{2} \\
25-34 \mathrm{~kg} / \mathrm{m}^{2} \\
\geq 35 \mathrm{~kg} / \mathrm{m}^{2}\end{array}$ & $\begin{array}{l}\text { Higher in-hospital mortality for BMI } \geq 35 \text { kg/m² (OR, } \\
\left.\text { 3.78; } 95 \% \mathrm{Cl}, 1.45-9.83 ; \text { vs. BMI } 25-34 \mathrm{~kg} / \mathrm{m}^{2}\right)\end{array}$ \\
\hline Ong et al. $(2020)^{30}$ & Singapore & 182 & $\begin{array}{l}\text { BMl } 25-30 \mathrm{~kg} / \mathrm{m}^{2}: 29(31.9) \\
30-35 \mathrm{~kg} / \mathrm{m}^{2}: 7(7.7) \\
>35 \mathrm{~kg} / \mathrm{m}^{2}: 4(4.4)\end{array}$ & $\begin{array}{l}<25 \mathrm{~kg} / \mathrm{m}^{2} \\
\geq 25 \mathrm{~kg} / \mathrm{m}^{2}\end{array}$ & $\begin{array}{l}\text { Higher disease severity of COVID-19 in BMI } \\
\geq 25 \mathrm{~kg} / \mathrm{m}^{2}\end{array}$ \\
\hline $\begin{array}{l}\text { Simonnet et al. } \\
(2020)^{7}\end{array}$ & France & 124 & $59(47.5)$ & Obesity: $\mathrm{BMI}>30 \mathrm{~kg} / \mathrm{m}^{2}$ & $\begin{array}{l}\text { Higher requirement for IMV in higher } \mathrm{BMI}(P<0.01) \text {, } \\
\text { being greatest in patients with } \mathrm{BMI}>35 \mathrm{~kg} / \mathrm{m}^{2} \\
(85.7 \%)\end{array}$ \\
\hline Peng et al. $(2020)^{31}$ & China & 112 & $33(29.5)$ & Obesity: $\mathrm{BMl}>25 \mathrm{~kg} / \mathrm{m}^{2}$ & $\begin{array}{l}\text { Higher proportion of in } \mathrm{BMl}>25 \mathrm{~kg} / \mathrm{m}^{2} \text { in mortality } \\
\text { cases compared to non-mortality cases ( } 88.24 \% \\
\text { vs. } 18.95 \%, P<0.001)\end{array}$ \\
\hline $\begin{array}{l}\text { Kalligeros et al. } \\
(2020)^{8}\end{array}$ & US & 103 & $49(47.5)$ & $\begin{array}{l}\text { Obesity: } \mathrm{BMl} \geq 30 \mathrm{~kg} / \mathrm{m}^{2} \\
\text { severe obesity: } \geq 35 \mathrm{~kg} / \mathrm{m}^{2}\end{array}$ & $\begin{array}{l}\text { Higher ICU admission (OR, 5.39; 95\% Cl, 1.13-25.64) } \\
\text { in severe obesity; increased IMV requirement in } \\
\text { obesity (OR, 6.85; 95\% Cl, 1.05-44.82) and in } \\
\text { severe obesity (OR, 9.99; 95\% Cl, 1.39-71.69) }\end{array}$ \\
\hline Kim et al. $(2020)^{9}$ & Korea & 28 & $5(17.9)$ & Obesity: $>30 \mathrm{~kg} / \mathrm{m}^{2}$ & $\begin{array}{l}\text { There were no data about impact of obesity on } \\
\text { COVID-19. }\end{array}$ \\
\hline Zheng et al. $(2020)^{10}$ & China & 66 & $45(68.2)$ & Obesity: $>25 \mathrm{~kg} / \mathrm{m}^{2}$ & $\begin{array}{l}\text { More severe COVID-19 illness in obesity and fatty } \\
\text { liver disease (OR, 5.8; 95\% Cl, 1.19-27.91) }\end{array}$ \\
\hline $\begin{array}{l}\text { Bhatraju et al. } \\
(2020)^{32}\end{array}$ & US & 24 & $13(54.2)$ & BMl of 23 patients were given. & $\begin{array}{l}\text { High ICU admission rate (56.5\%) in patients with } \\
\mathrm{BMI}>30 \mathrm{~kg} / \mathrm{m}^{2}\end{array}$ \\
\hline $\begin{array}{l}\text { Broderick et al. } \\
(2020)^{33}\end{array}$ & UK & 10 & $9(90)$ & $>40 \mathrm{~kg} / \mathrm{m}^{2}$ & $\begin{array}{l}\text { High tracheostomy rate in the weaning phase }(90 \%) \\
\text { in patients with } \mathrm{BMl}>30 \mathrm{~kg} / \mathrm{m}^{2}\end{array}$ \\
\hline Sutin et al. $(2020)^{34}$ & US & 2,094 & $587(28)$ & $\geq 30 \mathrm{~kg} / \mathrm{m}^{2}$ & BMI was not related to concern about COVID-19. \\
\hline
\end{tabular}

COVID-19, coronavirus disease 2019; BMI, body mass index; OR, odds ratio; Cl, confidence interval; IMV, invasive mechanical ventilation; ICU, intensive care unit.

ported that patients with DM are not at higher risk of SARS-CoV-2 infection than the general population. ${ }^{22}$

Glucose and glutamine are good sources of energy for viruses. ${ }^{35}$ A high glucose condition affects immune function, and conversely, dysregulated immune status is linked to macrovascular complications. ${ }^{36,37}$ A high blood glucose level in people with DM may provide a favorable environment for viruses to proliferate. In addition, infection with SARS CoV-1 has been reported to cause hyperglycemia in people without preexisting $\mathrm{DM} .{ }^{38}$ It is possible that $\mathrm{DM}$, particularly when not well controlled, may increase the risk of complications arising from COVID-19 and the risk of death. ${ }^{21,39}$

\section{POTENTIAL LINK BETWEEN COVID-19 AND OBESITY}

In addition to old age, smoking, and underlying CVD and DM, obesity is considered to be a risk factor for COVID-19 (Fig. 1). Several factors may affect the relationship between COVID-19 and 


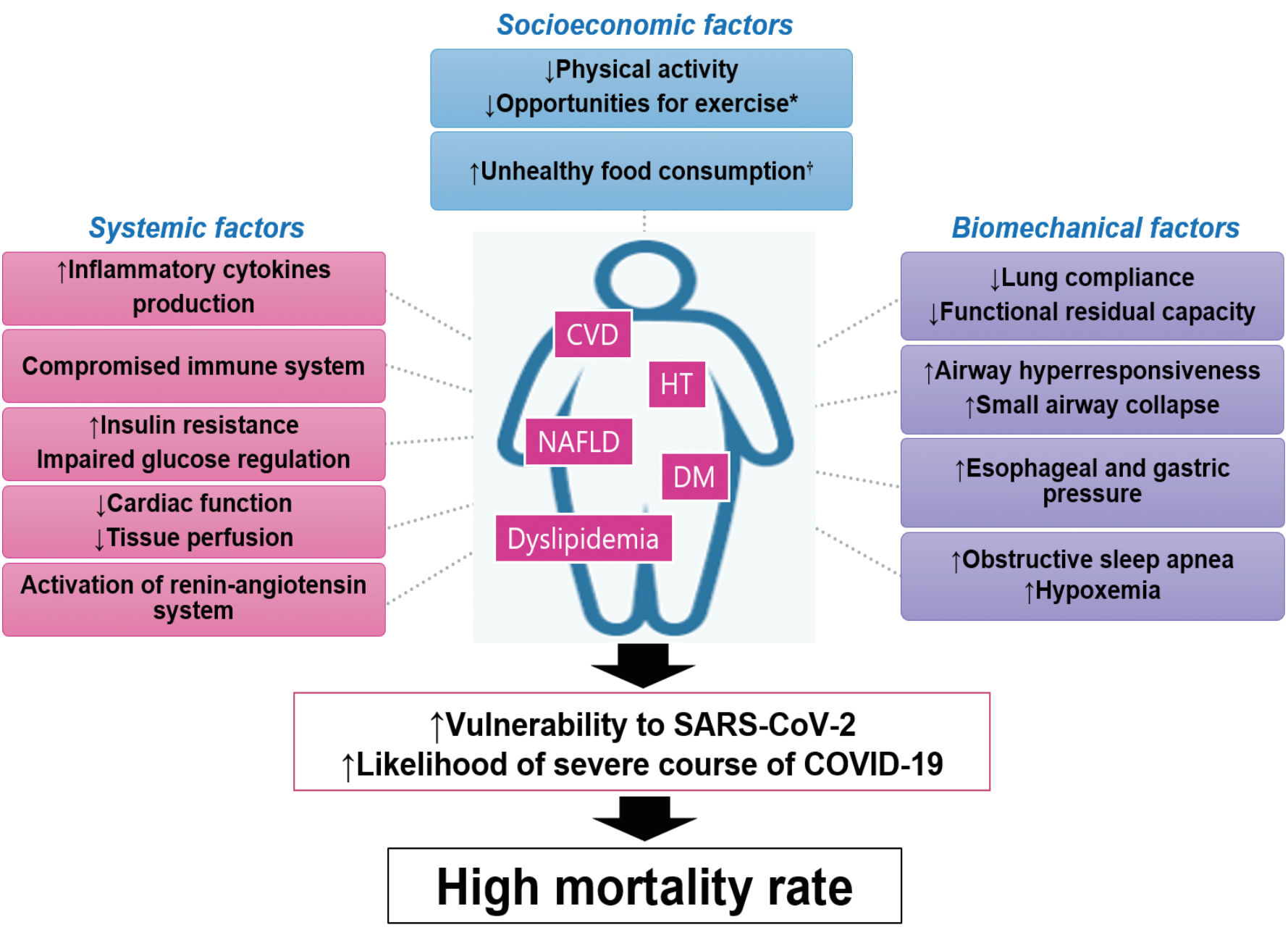

Figure 1. Potential mechanisms linking obesity to the vulnerability and severity of coronavirus disease 2019 (COVID-19). *Possibly related to the closing of public and private facilities such as community health centers, gyms, swimming pools, parks, and schools on the basis of quarantine strategies during the COVID-19 pandemic; ${ }^{\text {tPossibly }}$ related to the quarantine policies and financial effects during the COVID-19 pandemic. Socioeconomic factors: $\downarrow$ physical activity, ${ }^{40} \downarrow$ opportunities for exercise, ${ }^{41} \uparrow$ unhealthy food consumption. ${ }^{11}$ Systemic factors: $\uparrow$ inflammatory cytokine production, ${ }^{42-44}$ compromised immune system, ${ }_{1}^{45} \uparrow$ insulin resistance, ${ }^{46}$ impaired glucose regulation, ${ }^{46} \downarrow$ cardiac function, ${ }^{47} \downarrow$ tissue perfusion, ${ }^{48}$ activation of renin-angiotensin system. ${ }^{49,50}$ Biomechanical factors: $\downarrow$ lung compliance ${ }^{51} \downarrow$ functional residual capacity, ${ }^{51} \uparrow$ airway hyperresponsiveness, ${ }^{52} \uparrow$ small airway collapse, ${ }^{52} \uparrow$ esophageal and gastric pressure, ${ }^{53} \uparrow$ obstructive sleep apnea, ${ }^{54}$ 个hypoxemia ${ }^{54} \mathrm{CVD}$, cardiovascular disease; $\mathrm{HT}$, hypertension; NAFLD, nonalcoholic fatty liver disease; DM, diabetes mellitus; SARS-CoV-2, severe acute respiratory syndrome coronavirus 2.

obesity. Studies have reported that the immune system is frequently compromised in people with obesity and that COVID-19 affects the immune system, and these links may also worsen the complications of obesity. ${ }^{55,56}$ Of note, an excess production of interleukin 6 (IL-6) and other cytokines released in response to COVID-19 can induce a "cytokine storm" (hypercytokinemia), which is believed to increase the fatality of COVID-19. ${ }^{57}$ COVID-19 can also progress to severe respiratory illness and hypoxia, which may predispose people to being immobile and to gaining weight.
Increased risk of infection and inflammation in people with obesity

Obesity represents a state of chronic low-grade inflammation. Hyperplastic or hypertrophied adipose tissues directly secret various inflammatory products (Fig. 1), such as inflammatory cytokines, transforming growth factor- $\beta$, adipokines, monocyte chemoattractant protein 1 (MCP1), C-X-C motif chemokine ligand 5, hemostatic proteins, proteins affecting blood pressure, and angiogenic molecules. ${ }^{58,59}$ The main inflammatory cytokines derived from adipose tissues are tumor necrosis factor $\alpha$ (TNF- $\alpha$ ), IL-6, and IL-1. Increased TNF- $\alpha$ level in people with obesity reflects a 
potential role of this cytokine in obesity-associated inflammation, particularly insulin resistance. IL- 1 can activate transcription factors such as nuclear factor kappa-B (NF- $\mathrm{B}$ ), which increase inflammatory signaling and overexpression of vascular endothelial growth factor. Increased IL-6 level in obesity plays an important role in inflammation-associated carcinogenesis through the Janus kinase signal transducer and activator of transcription signaling pathway. ${ }^{60}$ In addition, IL-8, IL-10, interferon-gamma (IFN- $\gamma$ ), and inducible protein 10 are associated with obesity ${ }^{42}$ The delayed IFN responses during persistent chronic inflammation and obesogenesis may reflect reciprocal causality between obesity and virus susceptibility. ${ }^{43}$ Many cytokines released by dysfunctional hypertrophic adipocytes in obesity increase the recruitment of macrophages, which produce high amounts of proinflammatory molecules.

A cumulative effect of chronic inflammation and hypercytokinemia seems to bring about a hyperinflammatory response through macrophage active syndrome, especially in patients with severe
COVID-19 (Fig. 2). ${ }^{44}$ Inflammation subsequently leads to hypoxia and ischemia, which results in an oxidative stress state involving release of inflammatory proteins and reactive oxygen species that impair mitochondrial function. As a result, protein synthesis by hypertrophic and hypoxic white adipocytes is altered toward the production of cytokines and other inflammatory proteins, which may lead to metabolic disease. ${ }^{61,62} \mathrm{~A}$ vicious cycle between elevated release of cytokines and a state of increased metabolic inflammation, which leads to cytokine storm, occurs in patients infected with SARS-CoV-2 (Fig. 2). In patients with COVID-19, cytokine storm has been proposed to be the cause of the multiorgan failure in patients with severe disease. ${ }^{63,64}$ For example, hyperglycemia was reported in $51 \%$ of patients with SARS-CoV-2 infection. ${ }^{65}$ Hyperglycemia or type $2 \mathrm{DM}$, which is closely associated with obesity, has been suggested as an independent predictor of poor prognosis in patients with SARS-CoV-2. ${ }^{66}$

Several mechanisms have been proposed to explain how SARS-

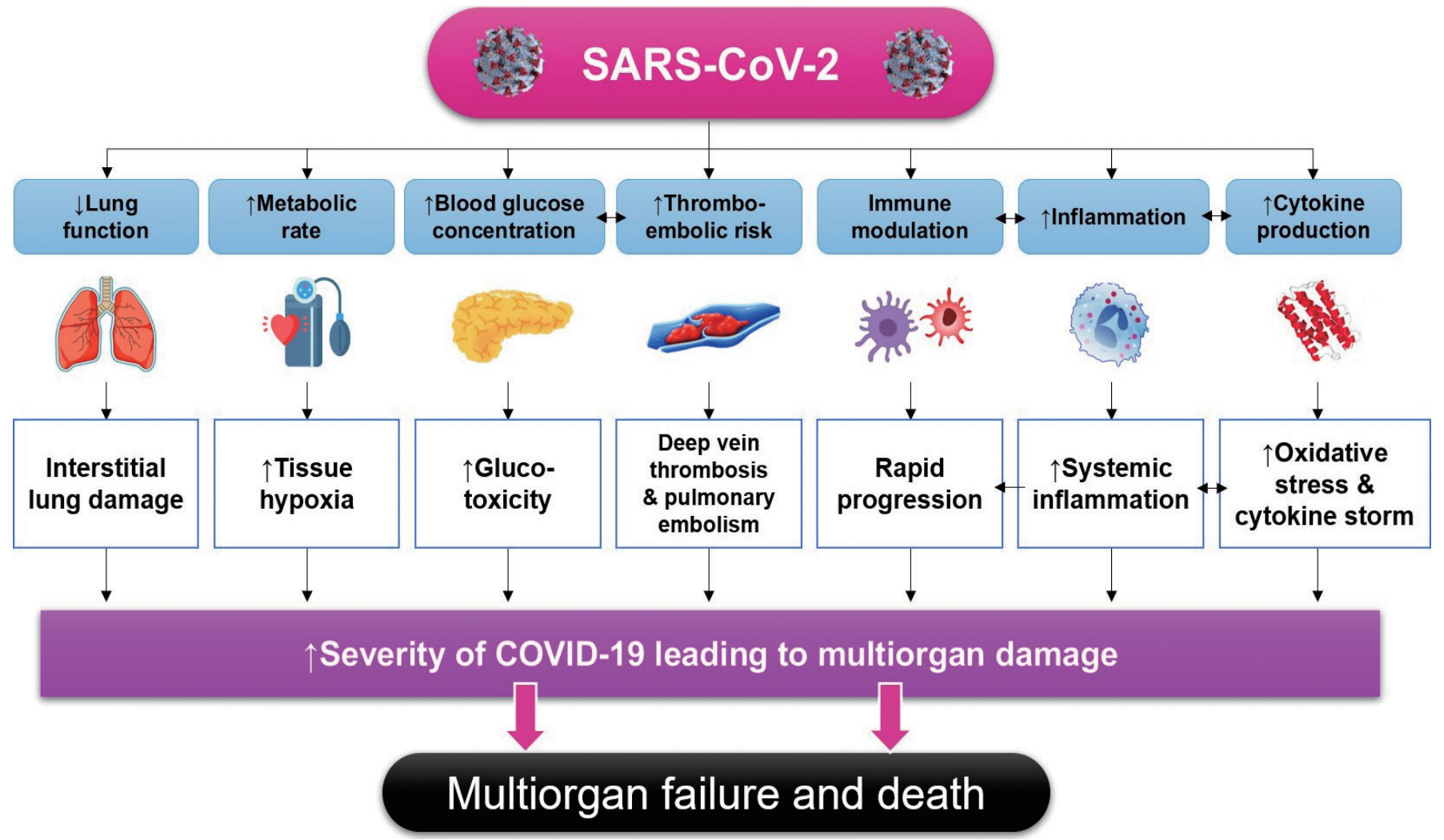

Figure 2. Potential processes after severe acute respiratory syndrome coronavirus 2 (SARS-CoV-2) infection in people with obesity. COVID-19, coronavirus disease 2019,

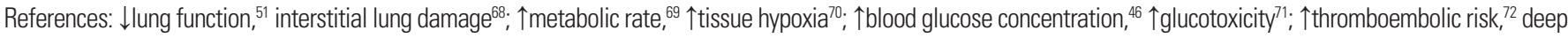
vein thrombosis \& pulmonary embolism³; immune modulation ${ }^{45}$; $\uparrow$ inflammation, ${ }^{42-44,60} \uparrow$ systemic inflammation ${ }^{42-44,60} ;$; cytokine production, $^{42,43,60} \uparrow$ oxidative stress and cytokine storm. ${ }^{74}$ 
CoV-2 infection induces inflammation and promotes insulin resistance (Fig. 2). ${ }^{46}$ Patients with COVID-19 exhibit increased production and secretion of inflammatory markers, such as C-reactive protein (CRP), D-dimer, ferritin, and IL- $6 .{ }^{67}$ In general, virus infection increases IL-6 levels and this increase is associated with increased risk of diabetic complications. ${ }^{75}$ Given its proinflammatory role in innate immunity, IL-6 level may correlate with disease severity and a procoagulant profile. ${ }^{76}$ By increasing oxidative stress, IL-6 can damage proteins, lipids, and DNA, and this damage may alter the organism's structure and function. Viral-induced production of IFN- $\gamma$ by natural killer cells causes insulin resistance in myocytes by downregulating insulin receptor transcription, thus causing insulin resistance. ${ }^{46}$

\section{Compromised immune system in people with obesity}

The mechanisms linking the poor prognosis of COVID-19 with obesity overlap with the pathways that regulate immune function (Fig. 2). Obesity leads to a state of chronic, low-grade inflammation that is associated with infiltration of inflammatory cells into adipose tissue under conditions of overnutrition. ${ }^{77,78}$ People with obesity have altered innate and adaptive immune responses, which are characterized by a state of chronic and low-grade inflammation and a higher circulating concentration of proinflammatory leptin and lower concentration of anti-inflammatory adiponectin. ${ }^{55}$ Consistent with this unfavorable hormone milieu, obesity alone can impair the immune responses to microbial agents, such as blunted macrophage activation and proinflammatory cytokine production upon macrophage stimulation. ${ }^{77}$ This reduced macrophage activation after exposure to an antigen may explain the poor vaccination success rate observed in people with obesity. ${ }^{79} \mathrm{~B}$ and $\mathrm{T}$ cell responses are also impaired in people with obesity, and this can increase the susceptibility to and delay the resolution of viral infection. ${ }^{77}$ Diet-induced obesity has been shown to impair memory $\mathrm{CD}^{+} \mathrm{T}$-cell responses to influenza virus infection, which resulted in increased mortality and viral titers in the lung, and worsened lung pathology. ${ }^{80}$

Physical inactivity is another important problem among people with obesity (Fig. 2). Reduced physical activity by itself ${ }^{40}$ or mediated by insulin resistance ${ }^{81}$ has been reported to impair the immune response to microbial agents at several steps, including macrophage activation and inhibition of proinflammatory cytokines. Obesity is associated with accelerated immune dysregulation, which may relate indirectly to the COVID-19 prognosis. The effects of obesity on immune function may be important to COVID-19 susceptibility and severity.

Proinflammatory cytokines of the $\mathrm{T}$ helper 1 signature are known to promote insulin resistance in obesity. Šestan et al. ${ }^{46}$ reported that virus-induced IFN- $\gamma$ increases muscle insulin resistance and anti-viral CD8 ${ }^{+}$T-cell responses. Virus-induced IFN- $\gamma$ may directly target skeletal muscle by downregulating its insulin receptors. Hyperinsulinemia increases antiviral immunity through direct stimulation of $\mathrm{CD}^{+}$effector T-cell function. In prediabetic mice with hepatic insulin resistance caused by diet-induced obesity, infection resulted in loss of glycemic control. ${ }^{46}$ Therefore, upon encountering pathogens, the immune system transiently reduces insulin sensitivity of skeletal muscle to promote antiviral immunity and induce hyperinsulinemia, which result in glucose intolerance.

Taken together, these findings suggest that obesity is associated with accelerated immune system aging and/or dysregulation and that these changes may relate indirectly to the COVID-19 prognosis. The immune modulation induced by obesity may be important to the susceptibility and severity of COVID-19 (Fig. 2).

\section{Implication of alterations in the renin-angiotensin system associated with obesity during the COVID-19 pandemic}

The renin-angiotensin system (RAS) appears to be activated in people with obesity. ${ }^{49,50}$ Normally, when blood flow decreases to the kidneys, the juxtaglomerular cells of the kidneys release renin, which activates the RAS. ${ }^{82}$ In obesity, there is inappropriate activation of the RAS in the context of increased sodium intake, sodium/ water retention, central blood volume, and blood pressure (Fig. 1). ${ }^{49}$ This metabolic dysregulation is associated with the expansion in visceral adipose tissue content, which leads to increased production of angiotensinogen (up to $30 \%$ of circulating angiotensinogen) and possibly elevated plasma renin activity. ${ }^{49,50}$ Massiera et al. ${ }^{83}$ showed that angiotensinogen-deficient mice exhibit impaired weight gain, which supports the association between obesity and the RAS.

A large amount of visceral adipose tissue induces release of insulin, which activates angiotensin type 1 receptors and influences the release of TNF- $\alpha$ and IL- 6 from adipocytes, resulting in activation 
of the RAS pathway. ${ }^{84}$ Of note, the organ involvement of SARS correlates with the organ expression of ACE2. In addition, the localization of ACE2 expression in the endocrine pancreas suggests that coronavirus enters islets using ACE2 as its receptor and damages islets, which leads to hyperglycemia. ${ }^{38}$ These data suggest that the RAS may be involved in the association between obesity and COVID-19.

\section{Other practical considerations}

People with obesity might be at a disadvantage after admission to the hospital or ICU, or when given medications in the ICU, which might contribute to their increased all-cause mortality. Older age and comorbidities such as CVD and DM can increase the severity of COVID-19, and other factors, such as use of steroid, can increase the amount of weight gained in people with obesity. ${ }^{84}$

Wearing proper masks is an important strategy to stop the spread of SARS-CoV-2. ${ }^{85}$ However, masks made in only one size may not be effective for people of different body sizes. For this reason, mask fitting tests for N95 masks are now used in some hospitals. In addition, people with morbid obesity can have difficulty with mask ventilation. ${ }^{86}$ The facial features of people with obesity may differ from those without, ${ }^{87,88}$ and it may be more difficult to find the right mask size for people with obesity.

Social distancing is recommended as the most effective way of slowing the spread of COVID-19. In a physically identical space, larger objects will be placed closer to each other. For this reason, it may be difficult for people with obesity to maintain social distance from other people, which may increase the risk of exposure to the virus. People with obesity tend to spend less time in work, recreation, and rest activities, and more time in activities of daily living than do those without obesity (Fig. 1) ${ }^{41}$ Restricting outdoor and indoor sports activities may have a greater impact on obese populations who are less likely to be physically active. The unprecedented boom in delivery industry, such as food-delivery services, may also contribute to the adoption of an unhealthy diet, which may have a stronger effect on people with obesity. Special attention to lifestyle factors, such as a healthy diet, may be needed for people with obesity and COVID-19.

\section{THERAPEUTIC CONSIDERATIONS FOR PEOPLE WITH OBESITY AND OBESITY-RELATED DISORDERS}

\section{Glucagon like peptide-1 analogues}

Glucagon-like peptide-1 (GLP1) analogues have an anti-inflammatory effect. For example, the mRNA levels of GLP1 receptors are downregulated in monocytes that have differentiated into macrophages. ${ }^{89}$ Treatment with exendin-4 decreases monocyte/macrophage accumulation and mRNA expression of inflammatory markers such as TNF- $\alpha$ and MCP1 in the arterial wall of $\mathrm{ApoE}^{-/-}$mice. ${ }^{90}$ Overexpression of GLP1 in balloon-injured vessels reduces monocyte infiltration and improves reendothelialization, which contribute to reduced neointimal formation. ${ }^{91}$ In mice fed a high-fat diet, treatment with liraglutide ( $30 \mu \mathrm{g} / \mathrm{kg}$ twice daily) decreases TNF- $\alpha$ expression and translocation of its downstream signal NF- $\mathrm{kB}$ $\mathrm{p} 65^{92}$ and adhesion of human monocytes to TNF- $\alpha$-activated human endothelial cells. ${ }^{92}$ In vitro MCP1 expression and NF-kB-p65 translocation also decrease significantly after GLP1 treatment. ${ }^{91}$ GLP1 analogues can shift the polarization profile of macrophages from M1 toward M2, ${ }^{93}$ supporting the anti-inflammatory properties of GLP1 analogues.

Liraglutide therapy has an anti-inflammatory effect by increasing nitric oxide production in endothelial cells. ${ }^{93}$ Liraglutide and semaglutide treatment reduce the development of atherosclerosis through mechanisms involving inflammatory pathways in $\mathrm{ApoE}^{-/}$ and LDL receptor $^{-/-}$mice. $^{94}$ In humans, GLP1 and GLP1 analogues have been shown to be beneficial for the treatment of chronic inflammatory diseases such as nonalcoholic fatty liver disease, ${ }^{95}$ atherosclerosis, ${ }^{91}$ and neurodegenerative disorders. ${ }^{96}$ Taken together, these findings suggest that GLP1 analogues have a protective role against atherosclerosis that is mediated by a dampening of the inflammatory pathways. ${ }^{97}$ Therefore, alleviation of inflammatory processes in the vascular system by these agents is a rationale for the recommendation to prescribe GLP1 analogues during the COVID-19 pandemic.

\section{Dipeptidyl peptidase-4 enzyme and inhibitors}

Dipeptidyl peptidase-4 (DPP4) inhibitors are one of the most frequently prescribed medications for patients with DM regardless 
of BMI. DPP4 inhibitors have both positive and negative effects on the immune system. For example, the use of DPP4 inhibitors was reported to increase the rate of certain types of infection, ${ }^{98}$ but basic and clinical studies support its anti-inflammatory properties. ${ }^{99}$

DPP4 are oligopeptides and play an important role in various biological processes, such as proliferation, T-cell immunity, and glucose homeostasis. ${ }^{100}$ The interaction between coronaviruses and this cellular type-II transmembrane protein DPP4 (CD26) has generated great interest recently. DPP4 serves as the receptor for Middle East respiratory syndrome coronavirus (MERS-CoV) in the same way as ACE2 is the receptor for SARS-CoV and SARS$\mathrm{CoV}-2 .{ }^{101}$ Experimental studies have suggested that certain polymorphisms of DPP4 are associated with a reduced rate of MERS$\mathrm{CoV}$ infection. ${ }^{102}$ This finding may explain the perplexing absence of MERS-CoV cases in Africa, despite the presence of the virus in camels, presumably because of the frequent presence of protective polymorphisms of DPP4 in Africans. ${ }^{102}$ In one in vitro study, sitagliptin, vildagliptin, and saxagliptin could not block the entry of coronaviruses into cells. ${ }^{103}$ Although ACE2 is the main receptor for SARS-CoV-2, a recent modeling study did not rule out its interaction with CD26 or DPP4. ${ }^{103}$ At present, there is insufficient evidence either for or against the use of DPP4 inhibitors in patients with DM and COVID-19. ${ }^{104}$

\section{ACE2 and potential therapeutic implications}

The physiological role of ACE2 counter-regulates the renin-angiotensin-aldosterone system (RAAS) ${ }^{105}$ Independent of the RAAS, ACE2 also regulates intestinal amino acid homeostasis and the gut microbiome. ${ }^{106}$ In COIVD-19, ACE2 on the respiratory epithelium serve as a main entry of SARS-CoV-2. ${ }^{107}$ Interaction of SARS-CoV with ACE2 is initiated via trimers of the SARS spike protein, which extends into a hydrophobic pocket of the ACE2 catalytic domain that is independent of its peptidase activity. ${ }^{108} \mathrm{ACE} 2$ is highly expressed in the lung as well as in the heart, endothelium, kidney, and gastrointestinal tract, and the tissue distribution of ACE2 overlaps with the tissue tropisms of SARS-CoV-2. ${ }^{109}$ This means that ACE2 expression may be implicated in the severe illness caused by COVID-19. Higher expression of ACE2 in patients with hypertension and CVD has been postulated as a factor that increases the susceptibility to SARS-CoV-2. ${ }^{108}$
By contrast, there is evidence that ACE2 may have a beneficial role in COVID-19. Both SARS-CoV infection and challenge with recombinant SARS spike protein trigger marked downregulation of ACE2 expression in the lung. ${ }^{110}$ Downregulation of ACE2 results in susceptibility of lung injury ${ }^{111}$ and unopposed RAAS activation. ${ }^{112}$ In animal models, elimination of ACE2 was associated with severe lung injury, which could be recovered by recombinant ACE2 protein. ${ }^{111}$ In addition, ACE2-knockout mice exhibited cardiac dysfunction, which could be reversed by concomitant deletion of $A C E .{ }^{113}$ Reduced ACE2 expression in cardiac injury has been confirmed in SARS infection ${ }^{114}$ and myocardial infarction. ${ }^{111}$ Given that the involvement of the cardiopulmonary system is a key factor for the severity of COVID-19, ACE2 may play a role in the prognosis of COVID-19.

People with obesity often also develop hypertension or heart failure. ${ }^{112} \mathrm{~A}$ large multicenter study has confirmed that hypertension can increase the risk of severe COVID-19 by as much as 1.7 times. ${ }^{19}$ RAAS inhibitors are the mainstay for treatment of hypertension and heart failure. Because RAAS inhibitors can increase the tissue expression of ACE2 in animal models, ${ }^{115}$ RAAS inhibitors may increase the susceptibility to COVID-19 and its severity after exposure to SARS-CoV-2. ${ }^{108}$ However, all classes of antihypertensive medication including RAAS inhibitors are not associated with a substantial increase in the risk of severe illness in COVID-19. ${ }^{116}$ The effect of RAAS inhibitors on ACE2 level or activity in human studies is controversial. Generally, ACE inhibition does not affect ACE2-directed angiotensin II metabolism, ${ }^{17,118}$ and only specific RAAS inhibitors appear to increase the ACE2 level. ${ }^{119,120}$ By contrast, RAAS inhibitors may potentiate the protective function of ACE2 against cardiopulmonary injury. ${ }^{121}$ A recent study of 417 COVID-19 patients showed that ACE inhibitors or angiotensin receptor blocker therapy was associated with a lower rate of severe disease, less systemic inflammation, and lower peak viral load compared with the use of other antihypertensive drugs. ${ }^{122}$

Despite uncertainties regarding RAAS inhibitors on the infectivity of SARS-CoV-2, there is clear potential for harm related to the withdrawal of RAAS inhibitors in patients concerned that RAAS inhibitors may be harmful in those with an unstable status, such as heart failure ${ }^{123}$ or myocardial infaction. ${ }^{124}$ Experts strongly recommend that patients should not stop taking their RAAS inhibitor 
during the COVID-19 pandemic. ${ }^{125}$

\section{Hydroxymethylglutaryl-CoA reductase inhibitors}

Hydroxymethylglutaryl-CoA reductase inhibitors or statins have anti-inflammatory properties. In the Justification for the Use of Statins in Prevention: an Intervention Trial Evaluating Rosuvastatin trial, rosuvastatin reduced the relative risk of major cardiovascular events by $44 \%$ in people without hyperlipidemia but with elevated high-sensitivity CRP level. ${ }^{126}$ In a viral pneumonia mouse model, simvastatin directly modulated antiviral inflammatory responses in lung tissues. ${ }^{127}$ In that study, simvastatin treatment attenuated airway inflammation, such as RANTES (regulated on activation, normal T-cell expressed and secreted) expression and neutrophil recruitments. ${ }^{127}$ Rosuvastatin therapy also has additional benefits including anti-inflammatory effects beyond the lipid-lowering property, which suggests that this drug has pleiotropic effects. ${ }^{128}$ These data support the favorable effects of statins on respiratory diseases. ${ }^{129}$ Statin therapy should be continued during the COVID-19 pandemic if there is no definite contraindication.

\section{CONCLUSION}

During the COVID-19 pandemic, people with obesity should maintain a heathy lifestyle. Regular exercise is essential to maintaining immunity. ${ }^{130}$ Healthy eating is also crucial for strengthening the immune system and reducing inflammation. ${ }^{130}$ People with obesity who experience symptoms such as cough, sputum, fever, or a sudden increase in blood glucose level should consult their physician immediately. The clinical guidelines for the management of obesity-related disorders should be followed closely. Health-care providers should make sure that their patients with obesity do not stop taking antiobesity agents, particularly GLP1 analogues, or medications for obesity-related disorders such as statin and ACE inhibitors or angiotensin receptor blockers, provided there is no contraindication to these patients taking these agents.

In conclusion, COVID-19 is a global pandemic and may pose considerable health hazard, especially for people with obesity. Obesity is a risk factor for poor outcomes of viral infection because of the deleterious effects of obesity on the immune system, which can lead to mortality in people with obesity with COVID-19. During the COVID-19 pandemic, it is important for people with obesity to maintain a healthy lifestyle, and their medications should be adjusted properly. Close monitoring of patients with obesity is required because of the restrictions imposed by the quarantine policies on physical activity and healthy eating. The optimal management strategy for these people warrants further investigation.

\section{CONFLICTS OF INTEREST}

The authors declare no conflict of interest.

\section{AUTHOR CONTRIBUTIONS}

Study concept and design: SL; acquisition of data: SL and SMS; analysis and interpretation of data: SL; drafting of the manuscript: all authors; critical revision of the manuscript: all authors; administrative, technical, or material support: SL and SMS; and study supervision: SL.

\section{REFERENCES}

1. Walls AC, Park YJ, Tortorici MA, Wall A, McGuire AT, Veesler D. Structure, function, and antigenicity of the SARSCoV-2 spike glycoprotein. Cell 2020;181:281-92.e6.

2. Zhang H, Penninger JM, Li Y, Zhong N, Slutsky AS. Angiotensin-converting enzyme 2 (ACE2) as a SARS-CoV-2 receptor: molecular mechanisms and potential therapeutic target. Intensive Care Med 2020;46:586-90.

3. Huang C, Wang Y, Li X, Ren L, Zhao J, Hu Y, et al. Clinical features of patients infected with 2019 novel coronavirus in Wuhan, China. Lancet 2020;395:497-506.

4. Wu Z, McGoogan JM. Characteristics of and important lessons from the Coronavirus Disease 2019 (COVID-19) outbreak in China: summary of a report of 72314 cases from the Chinese Center for Disease Control and Prevention. JAMA 2020;323:1239-42.

5. Zheng Y, Xu H, Yang M, Zeng Y, Chen H, Liu R, et al. Epidemiological characteristics and clinical features of 32 critical and 67 noncritical cases of COVID-19 in Chengdu. J Clin Virol 2020;127:104366. 
6. Hussain A, Vasas P, El-Hasani S. Letter to the Editor: obesity as a risk factor for greater severity of COVID-19 in patients with metabolic associated fatty liver disease. Metabolism 2020;108:154256.

7. Simonnet A, Chetboun M, Poissy J, Raverdy V, Noulette J, Duhamel A, et al. High prevalence of obesity in severe acute respiratory syndrome coronavirus-2 (SARS-CoV-2) requiring invasive mechanical ventilation. Obesity (Silver Spring) 2020 Apr 9 [Epub]. https://doi.org/10.1002/oby.22831

8. Kalligeros M, Shehadeh F, Mylona EK, Benitez G, Beckwith CG, Chan PA, et al. Association of obesity with disease severity among patients with coronavirus disease 2019. Obesity (Silver Spring) 2020 Apr 30 [Epub]. https://doi.org/10. v1002/oby.22859

9. Kim ES, Chin BS, Kang CK, Kim NJ, Kang YM, Choi JP, et al. Clinical course and outcomes of patients with severe acute respiratory syndrome coronavirus 2 infection: a preliminary report of the first 28 patients from the Korean cohort study on COVID-19. J Korean Med Sci 2020;35:e142.

10. Zheng KI, Gao F, Wang XB, Sun QF, Pan KH, Wang TY, et al. Letter to the Editor: obesity as a risk factor for greater severity of COVID-19 in patients with metabolic associated fatty liver disease. Metabolism 2020;108:154244.

11. Naja F, Hamadeh R. Nutrition amid the COVID-19 pandemic: a multi-level framework for action. Eur J Clin Nutr 2020 Apr 20 [Epub]. https://doi.org/10.1038/s41430-0200634-3

12. Kim TH, Park Y, Myung J, Han E. Food price trends in South Korea through time series analysis. Public Health 2018;165: 67-73.

13. Fleischhacker SE, Evenson KR, Rodriguez DA, Ammerman AS. A systematic review of fast food access studies. Obes Rev 2011;12:e460-71.

14. Pereira MA, Kartashov AI, Ebbeling CB, Van Horn L, Slattery ML, Jacobs DR Jr, et al. Fast-food habits, weight gain, and insulin resistance (the CARDIA study): 15-year prospective analysis. Lancet 2005;365:36-42.

15. Malik VS, Popkin BM, Bray GA, Després JP, Willett WC, $\mathrm{Hu}$ FB. Sugar-sweetened beverages and risk of metabolic syndrome and type 2 diabetes: a meta-analysis. Diabetes
Care 2010;33:2477-83.

16. Barone Gibbs B, Pettee Gabriel K, Carnethon MR, GaryWebb T, Jakicic JM, Rana JS, et al. Sedentary time, physical activity, and adiposity: cross-sectional and longitudinal associations in CARDIA. Am J Prev Med 2017;53:764-71.

17. Nightingale CM, Rudnicka AR, Donin AS, Sattar N, Cook DG, Whincup PH, et al. Screen time is associated with adiposity and insulin resistance in children. Arch Dis Child 2017;102:612-6.

18. Epidemiology Working Group for NCIP Epidemic Response, Chinese Center for Disease Control and Prevention. The epidemiological characteristics of an outbreak of 2019 novel coronavirus diseases (COVID-19) in China. Zhonghua Liu Xing Bing Xue Za Zhi 2020;41:145-51.

19. Guan WJ, Ni ZY, Hu Y, Liang WH, Ou CQ He JX, et al. Clinical characteristics of coronavirus disease 2019 in China. N Engl J Med 2020;382:1708-20.

20. Driggin E, Madhavan MV, Bikdeli B, Chuich T, Laracy J, Biondi-Zoccai G, et al. Cardiovascular considerations for patients, health care workers, and health systems during the COVID-19 pandemic. J Am Coll Cardiol 2020;75:2352-71.

21. Grasselli G, Zangrillo A, Zanella A, Antonelli M, Cabrini L, Castelli A, et al. Baseline characteristics and outcomes of 1591 patients infected with SARS-CoV-2 admitted to ICUs of the Lombardy region, Italy. JAMA 2020;323:1574-81.

22. Fadini GP, Morieri ML, Longato E, Avogaro A. Prevalence and impact of diabetes among people infected with SARSCoV-2. J Endocrinol Invest 2020;43:867-9.

23. CDC COVID-19 Response Team. Preliminary estimates of the prevalence of selected underlying health conditions among patients with coronavirus disease 2019 - United States, February 12-March 28, 2020. MMWR Morb Mortal Wkly Rep 2020;69:382-6.

24. Petrilli CM, Jones SA, Yang J, Rajagopalan H, O’Donnell L, Chernyak Y, et al. Factors associated with hospital admission and critical illness among 5279 people with coronavirus disease 2019 in New York City: prospective cohort study. BMJ 2020;369:m1966.

25. Klang E, Kassim G, Soffer S, Freeman R, Levin MA, Reich DL. Morbid obesity as an independent risk factor for COV- 
ID-19 mortality in hospitalized patients younger than 50 . Obesity (Silver Spring) 2020 May 23 [Epub]. https://doi. org/10.1002/oby.22913

26. Cai Q, Chen F, Wang T, Luo F, Liu X, Wu Q, et al. Obesity and COVID-19 severity in a designated hospital in Shenzhen, China. Diabetes Care 2020;43:1392-8.

27. Caussy C, Wallet F, Laville M, Disse E. Obesity is associated with severe forms of COVID-19. Obesity (Silver Spring) 2020 Apr 21 [Epub]. https://doi.org/10.1002/oby.22842

28. Huang R, Zhu L, Xue L, Liu L, Yan X, Wang J, et al. Clinical findings of patients with coronavirus disease 2019 in Jiangsu province, China: a retrospective, multi-center study. PLoS Negl Trop Dis 2020;14:e0008280.

29. Palaiodimos L, Kokkinidis DG, Li W, Karamanis D, Ognibene J, Arora S, et al. Severe obesity, increasing age and male sex are independently associated with worse in-hospital outcomes, and higher in-hospital mortality, in a cohort of patients with COVID-19 in the Bronx, New York. Metabolism 2020;108: 154262.

30. Ong SW, Young BE, Leo YS, Lye DC. Association of higher body mass index (BMI) with severe coronavirus disease 2019 (COVID-19) in younger patients. Clin Infect Dis 2020 May 8 [Epub]. https://doi.org/10.1093/cid/ciaa548

31. Peng YD, Meng K, Guan HQ, Leng L, Zhu RR, Wang BY, et al. Clinical characteristics and outcomes of 112 cardiovascular disease patients infected by 2019-nCoV. Zhonghua Xin Xue Guan Bing Za Zhi 2020;48:E004.

32. Bhatraju PK, Ghassemieh BJ, Nichols M, Kim R, Jerome KR, Nalla AK, et al. Covid-19 in critically ill patients in the Seattle region: case series. N Engl J Med 2020;382:2012-22.

33. Broderick D, Kyzas P, Baldwin AJ, Graham RM, Duncan T, Chaintoutis C, et al. Surgical tracheostomies in COVID-19 patients: a multidisciplinary approach and lessons learned. Oral Oncol 2020;106:104767.

34. Sutin AR, Robinson E, Daly M, Gerend MA, Stephan Y, Luchetti M, et al. Body mass index, weight discrimination, and psychological, behavioral, and interpersonal responses to the coronavirus pandemic. Obesity (Silver Spring) 2020 May 23 [Epub]. https://doi.org/10.1002/oby.22914

35. Thai M, Thaker SK, Feng J, Du Y, Hu H, Ting Wu T, et al.
MYC-induced reprogramming of glutamine catabolism supports optimal virus replication. Nat Commun 2015;6:8873.

36. Mehta P, McAuley DF, Brown M, Sanchez E, Tattersall RS, Manson JJ, et al. COVID-19: consider cytokine storm syndromes and immunosuppression. Lancet 2020;395:1033-4.

37. Zhang Y, Xiao M, Zhang S, Xia P, Cao W, Jiang W, et al. Coagulopathy and antiphospholipid antibodies in patients with Covid-19. N Engl J Med 2020;382:e38.

38. Yang JK, Lin SS, Ji XJ, Guo LM. Binding of SARS coronavirus to its receptor damages islets and causes acute diabetes. Acta Diabetol 2010;47:193-9.

39. Yang J, Zheng Y, Gou X, Pu K, Chen Z, Guo Q, et al. Prevalence of comorbidities and its effects in patients infected with SARS-CoV-2: a systematic review and meta-analysis. Int J Infect Dis 2020;94:91-5.

40. Zheng Q, Cui G, Chen J, Gao H, Wei Y, Uede T, et al. Regular exercise enhances the immune response against microbial antigens through up-regulation of toll-like receptor signaling pathways. Cell Physiol Biochem 2015;37:735-46.

41. Forhan M, Law M, Vrkljan BH, Taylor VH. Participation profile of adults with class III obesity. OTJR (Thorofare N J) 2011;31:135-42.

42. Sharabiani MT, Vermeulen R, Scoccianti C, Hosnijeh FS, Minelli L, Sacerdote C, et al. Immunologic profile of excessive body weight. Biomarkers 2011;16:243-51.

43. Honce R, Schultz-Cherry S. Impact of obesity on influenza a virus pathogenesis, immune response, and evolution. Front Immunol 2019;10:1071.

44. Korakas E, Ikonomidis I, Kousathana F, Balampanis K, Kountouri A, Raptis A, et al. Obesity and COVID-19: immune and metabolic derangement as a possible link to adverse clinical outcomes. Am J Physiol Endocrinol Metab 2020 May 27 [Epub]. https://doi.org/10.1152/ajpendo.00198. 2020

45. Frasca D, Blomberg BB. The impact of obesity and metabolic syndrome on vaccination success. Interdiscip Top Gerontol Geriatr 2020;43:86-97.

46. Šestan M, Marinović S, Kavazović I, Cekinović Đ, Wueest S, Turk Wensveen T, et al. Virus-induced interferon- $\gamma$ causes insulin resistance in skeletal muscle and derails glycemic 
control in obesity. Immunity 2018;49:164-77.e6.

47. de Divitiis O, Fazio S, Petitto M, Maddalena G, Contaldo F, Mancini M. Obesity and cardiac function. Circulation 1981; 64:477-82.

48. Levy BI, Schiffrin EL, Mourad JJ, Agostini D, Vicaut E, Safar $\mathrm{ME}$, et al. Impaired tissue perfusion: a pathology common to hypertension, obesity, and diabetes mellitus. Circulation 2008;118:968-76.

49. Sarzani R, Salvi F, Dessì-Fulgheri P, Rappelli A. Renin-angiotensin system, natriuretic peptides, obesity, metabolic syndrome, and hypertension: an integrated view in humans. J Hypertens 2008;26:831-43.

50. Andersen CJ, Murphy KE, Fernandez ML. Impact of obesity and metabolic syndrome on immunity. Adv Nutr 2016;7: 66-75.

51. Thomas PS, Cowen ER, Hulands G, Milledge JS. Respiratory function in the morbidly obese before and after weight loss. Thorax 1989;44:382-6.

52. Shore SA, Fredberg JJ. Obesity, smooth muscle, and airway hyperresponsiveness. J Allergy Clin Immunol 2005; 115 : 925-7.

53. Behazin N, Jones SB, Cohen RI, Loring SH. Respiratory restriction and elevated pleural and esophageal pressures in morbid obesity. J Appl Physiol (1985) 2010;108:212-8.

54. Li M, Li X, Lu Y. Obstructive sleep apnea syndrome and metabolic diseases. Endocrinology 2018;159:2670-5.

55. Cabandugama PK, Gardner MJ, Sowers JR. The renin angiotensin aldosterone system in obesity and hypertension: roles in the cardiorenal metabolic syndrome. Med Clin North Am 2017;101:129-37.

56. McNelis JC, Olefsky JM. Macrophages, immunity, and metabolic disease. Immunity 2014;41:36-48.

57. Jose RJ, Manuel A. COVID-19 cytokine storm: the interplay between inflammation and coagulation. Lancet Respir Med 2020;8:e46-7.

58. Evans AC, Papachristou GI, Whitcomb DC. Obesity and the risk of severe acute pancreatitis. Minerva Gastroenterol Dietol 2010;56:169-79.

59. Vartanian FE, Stepanova NI, Vladimirova LI. The health care and health status of the population of Sweden. Sov Zdravookhr
$1989 ;(7): 47-51$.

60. Michalakis K, Venihaki M, Mantzoros C, Vazaiou A, Ilias I, Gryparis A, et al. In prostate cancer, low adiponectin levels are not associated with insulin resistance. Eur J Clin Invest 2015;45:572-8.

61. Ellulu MS, Patimah I, Khaza'ai H, Rahmat A, Abed Y. Obesity and inflammation: the linking mechanism and the complications. Arch Med Sci 2017;13:851-63.

62. Stone TW, McPherson M, Gail Darlington L. Obesity and cancer: existing and new hypotheses for a causal connection. EBioMedicine 2018;30:14-28.

63. Zhang X, Wu K, Wang D, Yue X, Song D, Zhu Y, et al. Nucleocapsid protein of SARS-CoV activates interleukin-6 expression through cellular transcription factor NF-kappaB. Virology 2007;365:324-35.

64. Michalakis K, Ilias I. SARS-CoV-2 infection and obesity: common inflammatory and metabolic aspects. Diabetes Metab Syndr 2020;14:469-71.

65. Chen N, Zhou M, Dong X, Qu J, Gong F, Han Y, et al. Epidemiological and clinical characteristics of 99 cases of 2019 novel coronavirus pneumonia in Wuhan, China: a descriptive study. Lancet 2020;395:507-13.

66. Ilias I, Zabuliene L. Hyperglycemia and the novel Covid-19 infection: possible pathophysiologic mechanisms. Med Hypotheses 2020;139:109699.

67. Zhou F, Yu T, Du R, Fan G, Liu Y, Liu Z, et al. Clinical course and risk factors for mortality of adult inpatients with COVID-19 in Wuhan, China: a retrospective cohort study. Lancet 2020;395:1054-62.

68. Franks TJ, Chong PY, Chui P, Galvin JR, Lourens RM, Reid $\mathrm{AH}$, et al. Lung pathology of severe acute respiratory syndrome (SARS): a study of 8 autopsy cases from Singapore. Hum Pathol 2003;34:743-8.

69. Ravussin E, Burnand B, Schutz Y, Jéquier E. Twenty-four-hour energy expenditure and resting metabolic rate in obese, moderately obese, and control subjects. Am J Clin Nutr 1982;35: 566-73.

70. Hosogai N, Fukuhara A, Oshima K, Miyata Y, Tanaka S, Segawa $\mathrm{K}$, et al. Adipose tissue hypoxia in obesity and its impact on adipocytokine dysregulation. Diabetes 2007;56:901-11. 
71. Roseman HM. Progression from obesity to type 2 diabetes: lipotoxicity, glucotoxicity, and implications for management. J Manag Care Pharm 2005;11(6 Suppl B):S3-11.

72. Stein PD, Beemath A, Olson RE. Obesity as a risk factor in venous thromboembolism. Am J Med 2005;118:978-80.

73. Braekkan SK, Siegerink B, Lijfering WM, Hansen JB, Cannegieter SC, Rosendaal FR. Role of obesity in the etiology of deep vein thrombosis and pulmonary embolism: current epidemiological insights. Semin Thromb Hemost 2013;39: 533-40.

74. Ye Q, Wang B, Mao J. The pathogenesis and treatment of the 'Cytokine Storm' in COVID-19. J Infect 2020;80:607-13.

75. Hunter CA, Jones SA. IL-6 as a keystone cytokine in health and disease. Nat Immunol 2015;16:448-57.

76. Libby P, Simon DI. Inflammation and thrombosis: the clot thickens. Circulation 2001;103:1718-20.

77. Saltiel AR, Olefsky JM. Inflammatory mechanisms linking obesity and metabolic disease. J Clin Invest 2017;127:1-4.

78. Mraz M, Haluzik M. The role of adipose tissue immune cells in obesity and low-grade inflammation. J Endocrinol 2014;222:R113-27.

79. Karlsson EA, Hertz T, Johnson C, Mehle A, Krammer F, Schultz-Cherry S. Obesity outweighs protection conferred by adjuvanted influenza vaccination. mBio 2016;7:e01144-16.

80. Karlsson EA, Sheridan PA, Beck MA. Diet-induced obesity in mice reduces the maintenance of influenza-specific CD8+ memory T cells. J Nutr 2010;140:1691-7.

81. Reidy PT, Yonemura NM, Madsen JH, McKenzie AI, Mahmassani ZS, Rondina MT, et al. An accumulation of muscle macrophages is accompanied by altered insulin sensitivity after reduced activity and recovery. Acta Physiol (Oxf) 2019; 226:e13251.

82. Kumar V, Abbas AK, Fasuto N, Aster J. Robbins and Cotran pathologic basis of disease. 8th ed. Philadelphia (PA): Saunders Elselvier; 2010.

83. Massiera F, Seydoux J, Geloen A, Quignard-Boulange A, Turban S, Saint-Marc P, et al. Angiotensinogen-deficient mice exhibit impairment of diet-induced weight gain with alteration in adipose tissue development and increased locomotor activity. Endocrinology 2001;142:5220-5.
84. Lim S, Meigs JB. Links between ectopic fat and vascular disease in humans. Arterioscler Thromb Vasc Biol 2014;34: 1820-6.

85. Lim S, Yoon HI, Song KH, Kim ES, Kim HB, Fidsa. Face masks and containment of coronavirus disease 2019 (COVID-19): experience from South Korea. J Hosp Infect 2020 Jun 12 [Epub]. https://doi.org/10.1016/j.jhin.2020.06.017

86. Moon TS, Fox PE, Somasundaram A, Minhajuddin A, Gonzales MX, Pak TJ, et al. The influence of morbid obesity on difficult intubation and difficult mask ventilation. J Anesth 2019;33:96-102.

87. Ferrario VF, Dellavia C, Tartaglia GM, Turci M, Sforza C. Soft tissue facial morphology in obese adolescents: a threedimensional noninvasive assessment. Angle Orthod 2004; 74:37-42.

88. Lee BJ, Kim JY. Predicting visceral obesity based on facial characteristics. BMC Complement Altern Med 2014;14:248.

89. Nagashima M, Watanabe T, Terasaki M, Tomoyasu M, Nohtomi K, Kim-Kaneyama J, et al. Native incretins prevent the development of atherosclerotic lesions in apolipoprotein $\mathrm{E}$ knockout mice. Diabetologia 2011;54:2649-59.

90. Arakawa M, Mita T, Azuma K, Ebato C, Goto H, Nomiyama T, et al. Inhibition of monocyte adhesion to endothelial cells and attenuation of atherosclerotic lesion by a glucagonlike peptide-1 receptor agonist, exendin-4. Diabetes 2010; 59:1030-7.

91. Lim S, Lee GY, Park HS, Lee DH, Tae Jung O, Kyoung Min $\mathrm{K}$, et al. Attenuation of carotid neointimal formation after direct delivery of a recombinant adenovirus expressing glucagon-like peptide-1 in diabetic rats. Cardiovasc Res 2017; 113:183-94.

92. Noyan-Ashraf MH, Shikatani EA, Schuiki I, Mukovozov I, Wu J, Li RK, et al. A glucagon-like peptide-1 analog reverses the molecular pathology and cardiac dysfunction of a mouse model of obesity. Circulation 2013;127:74-85.

93. Shiraishi D, Fujiwara Y, Komohara Y, Mizuta H, Takeya M. Glucagon-like peptide-1 (GLP-1) induces M2 polarization of human macrophages via STAT3 activation. Biochem Biophys Res Commun 2012;425:304-8.

94. Rakipovski G, Rolin B, Nøhr J, Klewe I, Frederiksen KS, 
Augustin R, et al. The GLP-1 analogs liraglutide and semaglutide reduce atherosclerosis in $\mathrm{ApoE}^{-/-}$and $\mathrm{LDLr}^{-/-}$mice by a mechanism that includes inflammatory pathways. JACC Basic Transl Sci 2018;3:844-57.

95. Wang XC, Gusdon AM, Liu H, Qu S. Effects of glucagonlike peptide-1 receptor agonists on non-alcoholic fatty liver disease and inflammation. World J Gastroenterol 2014;20: 14821-30.

96. Athauda D, Maclagan K, Skene SS, Bajwa-Joseph M, Letchford D, Chowdhury K, et al. Exenatide once weekly versus placebo in Parkinson's disease: a randomised, double-blind, placebo-controlled trial. Lancet 2017;390:1664-75.

97. Lim S, Kim KM, Nauck MA. Glucagon-like peptide-1 receptor agonists and cardiovascular events: class effects versus individual patterns. Trends Endocrinol Metab 2018;29:238-48.

98. Gorricho J, Garjón J, Alonso A, Celaya MC, Saiz LC, Erviti J, et al. Use of oral antidiabetic agents and risk of communityacquired pneumonia: a nested case-control study. Br J Clin Pharmacol 2017;83:2034-44.

99. Lim S, Choi SH, Shin H, Cho BJ, Park HS, Ahn BY, et al. Effect of a dipeptidyl peptidase-IV inhibitor, des-fluoro-sitagliptin, on neointimal formation after balloon injury in rats. PLoS One 2012;7:e35007.

100. Mentlein R. Dipeptidyl-peptidase IV (CD26): role in the inactivation of regulatory peptides. Regul Pept 1999;85:9-24.

101. Gierer S, Bertram S, Kaup F, Wrensch F, Heurich A, KrämerKühl A, et al. The spike protein of the emerging betacoronavirus EMC uses a novel coronavirus receptor for entry, can be activated by TMPRSS2, and is targeted by neutralizing antibodies. J Virol 2013;87:5502-11.

102. Kleine-Weber H, Schroeder S, Krüger N, Prokscha A, Naim HY, Müller MA, et al. Polymorphisms in dipeptidyl peptidase 4 reduce host cell entry of Middle East respiratory syndrome coronavirus. Emerg Microbes Infect 2020;9:155-68.

103. Vankadari N, Wilce JA. Emerging WuHan (COVID-19) coronavirus: glycan shield and structure prediction of spike glycoprotein and its interaction with human CD26. Emerg Microbes Infect 2020;9:601-4.

104. Iacobellis G. COVID-19 and diabetes: can DPP4 inhibition play a role? Diabetes Res Clin Pract 2020;162:108125.
105. Kuba K, Imai Y, Ohto-Nakanishi T, Penninger JM. Trilogy of ACE2: a peptidase in the renin-angiotensin system, a SARS receptor, and a partner for amino acid transporters. Pharmacol Ther 2010;128:119-28.

106. Hashimoto T, Perlot T, Rehman A, Trichereau J, Ishiguro H, Paolino M, et al. ACE2 links amino acid malnutrition to microbial ecology and intestinal inflammation. Nature 2012; 487:477-81.

107. Li W, Moore MJ, Vasilieva N, Sui J, Wong SK, Berne MA, et al. Angiotensin-converting enzyme 2 is a functional receptor for the SARS coronavirus. Nature 2003;426:450-4.

108. South AM, Diz DI, Chappell MC. COVID-19, ACE2, and the cardiovascular consequences. Am J Physiol Heart Circ Physiol 2020;318:H1084-90.

109. Yan T, Xiao R, Lin G. Angiotensin-converting enzyme 2 in severe acute respiratory syndrome coronavirus and SARSCoV-2: a double-edged sword? FASEB J 2020;34:6017-26.

110. Kuba K, Imai Y, Rao S, Gao H, Guo F, Guan B, et al. A crucial role of angiotensin converting enzyme 2 (ACE2) in SARS coronavirus-induced lung injury. Nat Med 2005;11: 875-9.

111. Kassiri Z, Zhong J, Guo D, Basu R, Wang X, Liu PP, et al. Loss of angiotensin-converting enzyme 2 accelerates maladaptive left ventricular remodeling in response to myocardial infarction. Circ Heart Fail 2009;2:446-55.

112. Seo MH, Lee WY, Kim SS, Kang JH, Kang JH, Kim KK, et al. 2018 Korean Society for the Study of Obesity Guideline for the Management of Obesity in Korea. J Obes Metab Syndr 2019;28:40-5.

113. Crackower MA, Sarao R, Oudit GY, Yagil C, Kozieradzki I, Scanga SE, et al. Angiotensin-converting enzyme 2 is an essential regulator of heart function. Nature 2002;417:822-8.

114. Oudit GY, Kassiri Z, Jiang C, Liu PP, Poutanen SM, Penninger JM, et al. SARS-coronavirus modulation of myocardial ACE2 expression and inflammation in patients with SARS. Eur J Clin Invest 2009;39:618-25.

115. Ferrario CM, Jessup J, Chappell MC, Averill DB, Brosnihan $\mathrm{KB}$, Tallant EA, et al. Effect of angiotensin-converting enzyme inhibition and angiotensin II receptor blockers on cardiac angiotensin-converting enzyme 2. Circulation 2005; 
111:2605-10

116. Reynolds HR, Adhikari S, Pulgarin C, Troxel AB, Iturrate E, Johnson SB, et al. Renin-angiotensin-aldosterone system inhibitors and risk of Covid-19. N Engl J Med 2020;382:2441-8.

117. Campbell DJ, Zeitz CJ, Esler MD, Horowitz JD. Evidence against a major role for angiotensin converting enzyme-related carboxypeptidase (ACE2) in angiotensin peptide metabolism in the human coronary circulation. J Hypertens 2004; 22:1971-6.

118. Ramchand J, Patel SK, Srivastava PM, Farouque O, Burrell LM. Elevated plasma angiotensin converting enzyme 2 activity is an independent predictor of major adverse cardiac events in patients with obstructive coronary artery disease. PLoS One 2018;13:e0198144.

119. Furuhashi M, Moniwa N, Mita T, Fuseya T, Ishimura S, Ohno $\mathrm{K}$, et al. Urinary angiotensin-converting enzyme 2 in hypertensive patients may be increased by olmesartan, an angiotensin II receptor blocker. Am J Hypertens 2015;28:15-21.

120. Luque M, Martin P, Martell N, Fernandez C, Brosnihan KB, Ferrario CM. Effects of captopril related to increased levels of prostacyclin and angiotensin-(1-7) in essential hypertension. J Hypertens 1996;14:799-805.

121. Gheblawi M, Wang K, Viveiros A, Nguyen Q, Zhong JC, Turner AJ, et al. Angiotensin-converting enzyme 2: SARS$\mathrm{CoV}-2$ receptor and regulator of the renin-angiotensin system: celebrating the 20th anniversary of the discovery of ACE2. Circ Res 2020;126:1456-74.

122. Meng J, Xiao G, Zhang J, He X, Ou M, Bi J, et al. Renin-angiotensin system inhibitors improve the clinical outcomes of COVID-19 patients with hypertension. Emerg Microbes Infect 2020;9:757-60.

123. Pflugfelder PW, Baird MG, Tonkon MJ, DiBianco R, Pitt B.
Clinical consequences of angiotensin-converting enzyme inhibitor withdrawal in chronic heart failure: a double-blind, placebo-controlled study of quinapril: the Quinapril Heart Failure Trial Investigators. J Am Coll Cardiol 1993;22:155763.

124. Indications for ACE inhibitors in the early treatment of acute myocardial infarction: systematic overview of individual data from 100,000 patients in randomized trials. ACE Inhibitor Myocardial Infarction Collaborative Group. Circulation 1998;97:2202-12.

125. Danser AH, Epstein M, Batlle D. Renin-angiotensin system blockers and the COVID-19 pandemic: at present there is no evidence to abandon renin-angiotensin system blockers. Hypertension 2020;75:1382-5.

126. Ridker PM, Danielson E, Fonseca FA, Genest J, Gotto AM Jr, Kastelein JJ, et al. Rosuvastatin to prevent vascular events in men and women with elevated C-reactive protein. N Engl J Med 2008;359:2195-207.

127. Lee CS, Yi EH, Lee JK, Won C, Lee YJ, Shin MK, et al. Simvastatin suppresses RANTES-mediated neutrophilia in polyinosinic-polycytidylic acid-induced pneumonia. Eur Respir J 2013;41:1147-56.

128. Oesterle A, Laufs U, Liao JK. Pleiotropic effects of statins on the cardiovascular system. Circ Res 2017;120:229-43.

129. Frost FJ, Petersen H, Tollestrup K, Skipper B. Influenza and COPD mortality protection as pleiotropic, dose-dependent effects of statins. Chest 2007;131:1006-12.

130. Lim S, Lim H, Després JP. Collateral damage of the COVID-19 pandemic on nutritional quality and physical activity: perspective from South Korea. Obesity (Silver Spring) 2020 June 15 [Epub]. https://doi.org/10.1002/oby.22935 